\title{
Evaluation of Regional Financial Management Based on Local Government Information Systems
}

\author{
Maitsarana Ishmaturahwa ${ }^{1}$ Sulaiman Sulaiman ${ }^{1}$ Rita Martini $^{1}{ }^{1} *$ M. Thoyib ${ }^{1}$ \\ Kartika Rachma Sari ${ }^{1}$ \\ ${ }^{1}$ Accounting Department, Polytechnic State of Sriwijaya, Palembang 30139, Indonesia \\ *Corresponding author. Email: ritamartini@polsri.ac.id
}

\begin{abstract}
The implementation of local government information systems (SIPD) needs to be evaluated to assess the effectiveness of local governments in managing their finances. Based on Regulation of the Minister of Home Affairs of the Republic of Indonesia Number 77 of 2020, the difficulties discovered have not been applied to SIPD optimally in the Regional Secretariat of South Sumatra Province. This is due to a lack of application readiness and complicated laws around its application. The government should immediately make system adjustments and make technical guidelines for the use of applications.
\end{abstract}

Keywords: Information system, governance, financial

\section{INTRODUCTION}

For the integrated management of financial reporting administration of Local Government Organizations (OPD), an electronic-based government system (SPBE) must be used [1]. The Director General of the Building Regional Development of Ministry of Home Affairs is in charge of managing and developing SIPD, an integrated information system. SIPD is an integrated system for planning regional development that includes regional development information governance, regional financial data, and other integrated local government data [2].

The Regional Secretariat of South Sumatra Province has implemented the use of SIPD applications in the implementation of regional financial management. Since 2014, this OPD applies the use of the SIMDA finance application, which is strengthened by approval on a memorandum of understanding (MoU) from (17) seventeen district/city governments in South Sumatra, the Financial and Development Supervision Agency (BPKP) and Bank Sumatra Selatan Bangka Belitung [3]. The Regional Secretariat of South Sumatra Province, on the other hand, has been implementing SIPD and SIMDA finance at the same time since the Minister of Home Affairs of the Republic of Indonesia (Permendagri) issued Regulation Number 77 of 2020 [4 ].

Evaluating the application of SIPD, especially in the Regional Financial Information System (SIKD) section is a form of effort to assess how well and successfully the application is used in regional financial management in accordance with applicable laws and regulations. With the establishment of the Minister of Home Affairs of the Republic of Indonesia Number 77 of 2020 on Technical Guidelines for Regional Financial Management [4], in regional financial management was changed from the use of SIMDA Finance to Local Government Information System (SIPD).

The Regional Secretariat of South Sumatra Province itself has established the use of SIPD since February 18, 2021, but in its implementation the Regional Secretariat of South Sumatra Province still uses SIMDA finance and SIPD applications simultaneously. However, the application of SIPD itself is still limited only to the planning and budgeting stage, while for the management stage to the reporting and accountability of SIPD cannot be used because of various things including the readiness of the system itself which causes its application to be incompatible with the provisions of the Minister of Home Affairs of the Republic of Indonesia Number 77 of 2020 [4], while the implementation of governance must refer to the laws and regulations that have been established [5].

\section{LITERATURE REVIEW AND RESEARCH HYPOTHESES}

SIPD is the management of regional development information, regional financial information, and other local government information that is interconnected to be 
utilized in the implementation of regional development. SIPD itself consists of three types, namely Regional Building Information System, Regional Financial Information System, and Other Local Government Information Systems. The development of SIPD has been used as a unifying tool for all information resources owned, making it easier for all parties concerned to manage and utilize information available for the public and government interests. In an effort to achieve this, it is necessary to revamp all aspects related to the development of SIPD [6], namely:

1. Superstructure, related to regulations, training/ education, and readiness of human resources

2. Network infrastructure concerns telecommunications technical equipment and internet networks

3. Application, is a SIPD that supports a national integrated SPBE

4. Data content infrastructure contained in SIPD.

The local government is required to prepare financial statements to account for the region's financial management under the laws and regulations. Accounting and financial reporting policy in the region is governed by Director General of Regional Financial Development Ministry [1] [5].

This statement focuses solely on the evaluation of SIPD implementation in conjunction with the Ministry of Home Affairs' Permendagri Number 77 of 2020 on Technical Guidelines for Regional Financial Management, which implements the provisions of Article 221 paragraph (1) of Government Regulation Number 12 of 2019 on Regional Financial Management [4] and [5].

\section{RESEARCH METHODOLOGY}

Data is collected through research in the form of observations by making direct observations in the field, in this case the Regional Secretariat of South Sumatra Province. Interviews are conducted with parties who handle SIPD. In addition, it is also equipped with literature studies, where existing documents are studied to obtain data and information including documents, journals, and related articles. The data studied includes primary data and secondary data.

\section{RESULT AND DISCUSSION}

\subsection{Result}

Based on the Minister of Home Affairs of the Republic of Indonesia Number 77 of 2020, SIPD must be applied to all stages of regional financial management ranging from planning, budgeting, implementation, management, reporting, accountability, and supervision of local finance [4]. Such as the preparation of local government work plans, the preparation of regional device work units, budgeting, revenue, and regional spending (APBD) including in the creation of Budget Implementation Documents (DPA) to the Provision of Funds (SPD), Letter of Provision of Funds (SPD), management of regional revenues, implementation and management of regional finances.

Such as in the case of the creation of Payment Request Letter (SPP), Warrant of Payment (SPM), Warrant of Disbursement of Funds (SP2D), to Letter of Accountability (SPJ), accounting and reporting includes all transaction recording processes to the journal, to the creation of regional financial statements such as Budget Realization Report (LRA), Balance Sheet, Cash Flow Statement (LAK), up to Notes on Financial Statements (CALK), and procurement of goods and services. If this is not implemented in the management of regional finances, it will have an influence on the General Transfer Fund being delayed or withheld in accordance with the rules and regulations at the Minister's request.

SIPD in regional financial management only at the planning and budgeting stage precisely in the Regional Development Information System contained by the planning, budgeting, and evaluation sub-section described in Figure 1.

For the next stage, including the implementation, management, reporting, accountability, and supervision of regional finance, regional revenue management, implementation and management of regional finance, accounting and reporting, and procurement of goods and services, the Regional Secretariat of South Sumatra Province uses the SIMDA Finance application [5]. The application as a companion to the use of SIPD applications that cannot be applied to the maximum. 


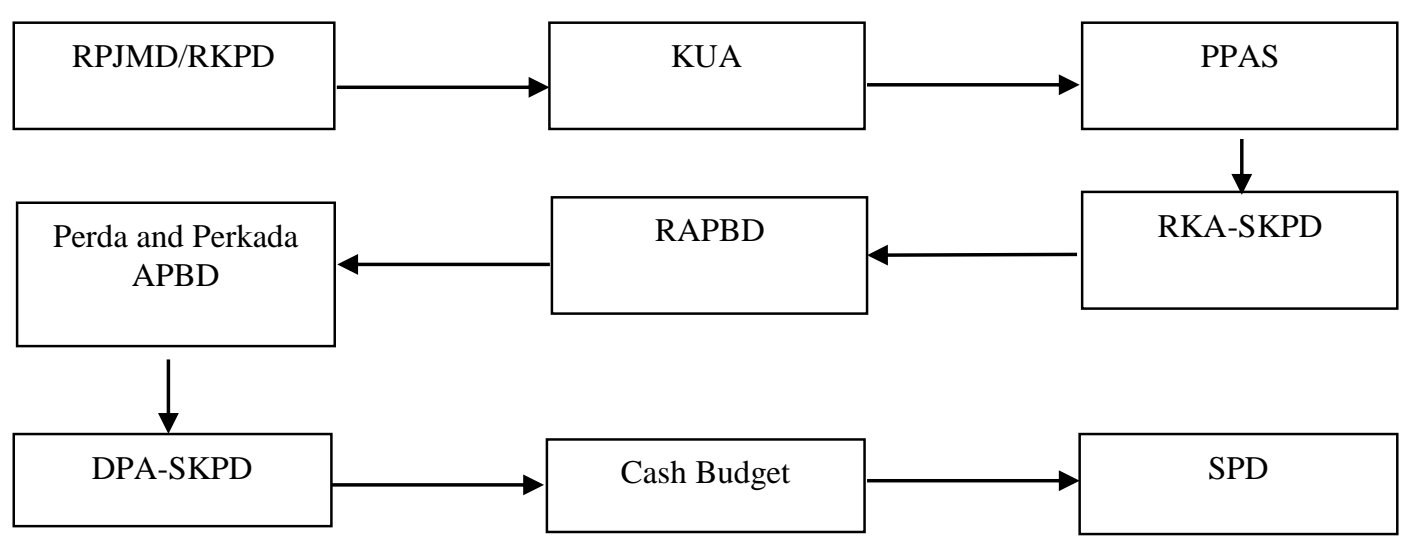

Information:

$\begin{array}{ll}\text { RPJMD } & =\text { Regional Medium-Term Development Plan } \\ \text { RKPD } & =\text { Local Government Work Plan } \\ \text { KUA } & =\text { General Budget Policy } \\ \text { PPAS } & =\text { Priority Temporary Budget Ceiling } \\ \text { RKA-SKPD } & =\text { Work Plan and Regional Device Work Unit Budget } \\ \text { RAPBD } & =\text { Regional Revenue and Spending Budget Plan } \\ \text { Perda APBD } & =\text { Local Regulations on APBD } \\ \text { Perkada APBD } & =\text { Regional Head Regulation on APBD (APBD Description) } \\ \text { DPA-SKPD } & =\text { SKPD Budget Implementation Document } \\ \text { SPD } & =\text { Letter of Provision of Funds }\end{array}$

Source: Data Processed, 2021

Figure 1. Document Management at the Planning and Budgeting Stage

\subsection{Discussion}

There is a difference between the application of SIPD in the Regional Secretariat of South Sumatra Province and listed in the Minister of Home Affairs of the Republic of Indonesia Number 77 of 2020 [4]. Not optimal use of SIPD in regional financial management at the Secretariat of South Sumatra Province in terms of regional revenue management, implementation and management of regional finance, accounting and reporting, and procurement of goods and services caused by various factors.

Several factors that cause the optimal use of SIPD in regional financial management in the Regional Secretariat of South Sumatra Province [2] and [7]. The first factor, there are no derivative rules from local governments as well as pilot projects or more detailed guidance on the use of SIPD in regional financial management. Second, there is often a system error when inputting data at the management stage caused by the unpreparedness of the application and also an unstable internet connection. Third, the database cannot be accessed at the reporting stage. Another factor is the convoluted regulation for reporting constraints to the central side.

\section{CONCLUSION}

There is a difference between the implementation of SIPD in the Regional Secretariat of South Sumatra Province and stated in the Minister of Home Affairs of the Republic of Indonesia Number 77 of 2020 on Technical Guidelines for Regional Financial 
Management which causes the optimal application of SIPD in regional financial management, namely in terms of regional revenue management, implementation and management of regional finance, accounting and reporting, and procurement of goods and services caused by various factors, Among them, there are no derivative rules and more detailed guidelines related to the use of SIPD in regional financial management, as well as the unpreparedness of the system itself.

It is important to make improvements to all aspects related to the development of SIPD. SIPD is expected to be applied optimally in accordance with the Minister of Home Affairs of the Republic of Indonesia Number 77 of 2020 on Technical Guidelines for Regional Financial Management and eliminate the differences that exist between application in the field and written regulations.

\section{ACKNOWLEDGMENT}

Thankfully acknowledges scientific dialogue with our Indonesian counterparts from the State Polytechnic of Sriwijaya. The authors would like to thank the anonymous reviewers who provided feedback on this presentation at the $5^{\text {th }}$ FIRST 2021 International Conference. Thank you also to the reviewers who provided feedback during the current review process.

\section{REFERENCES}

[1] Direktorat Jenderal Bina Keuangan Daerah Kementerian Dalam Negeri Republik Indonesia. (2021). Peraturan Menteri Dalam Negeri tentang Pedoman Teknis Pegelolaan Keuangan Daerah. (https://bulelengkab.go.id/assets/instansikab/60/ban kdata/peraturan-menteri-dalam-negeri-tentangpedoman-teknis-pengelolaan-keuangan-daerah12.pdf).

[2] Martini, R., Agustin, R., \& Sari, K. R. (2020). Accrual Discretion Policy on Excess/Less Budget Financing at the Provincial Level. TEST Engineering \& Management, 82, 9925-9935.

[3] Wulandari, Dinda. (2014). Sumsel Terapkan Simda Terintegrasi.

(https://kabar24.bisnis.com/read/20140914/78/2571 90/sumsel-terapkan-simda-terintegrasi)

[4] Republik Indonesia. (2020). Peraturan Menteri Dalam Negeri Republik Indonesia Nomor 77 Tahun 2020 Tentang Pedoman Teknis Pengelolaan Keuangan Daerah. Jakarta.

[5] Republik Indonesia. (2019). Peraturan Menteri Dalam Negeri Republik Indonesia Nomor 70 Tahun 2019 tentang Sistem Informasi Pemerintahan Daerah. Jakarta.

[6] Sudianing, Ni Ketut, \& Ketut Agus Seputra. (2019). Peran Sistem Infromasi Pemerintahan Daerah dalam Menunjang Peningkatan Kualitas Perencanaan Pembangunan Daerah.

[7] Martini, R., Sari, K. R., Somadi, T., \& Karman, I. W. (2019). Financial Independence of the South Sumatra Regional Government" Proceedings of the International Conference on Applied Science and Technology 2019-Social Sciences Track (iCASTSS 2019). 354, pp. 360-364. Denpasar: Atlantis Press. https://doi.org/10.2991/icastss-19.2019.75 